\title{
Analisis Penerapan Sistem Informasi Manajemen pada Aplikasi Tiket.com
}

\author{
Rifgi AGIANTO * \\ Sekolah Tinggi IImu Ekonomi STEMBI \\ Jl. Buah Batu No.26, Bandung, Provinsi Jawa Barat, Indonesia \\ rifgiagi21@gmail.com \\ Mochammad Noor Arif WIRASAPUTRA \\ Sekolah Tinggi IImu Ekonomi STEMBI \\ J. Buah Batu No.26, Bandung, Provinsi Jawa Barat, Indonesia \\ mhmmdnrarf@gmail.com \\ Ricky FIRMANSYAH \\ Universitas Ars \\ Jl. Sekolah Internasional No.1-2, Bandung, Provinsi Jawa Barat, Indonesia \\ ricky@ars.ac.id
}

\section{Article's history:}

Received 2 December 2020; Received in revised form 12 January 2021; Accepted 29 January, 2021; Published 28 February 2021. All rights reserved to the Lembaga Otonom Lembaga Informasi dan Riset Indonesia (KITA INFO dan RISET).

Suggested citation:

Agianto, R., Wirasaputra, A.N.M., Firmansyah, R. 2021. Analisis Penerapan Sistem Informasi Manajemen Pada Aplikasi Tiket.com. JEMSI (Jurnal Ekonomi, Manajemen, dan Akuntansi), Volume 7 (1): 1-8. DOI: https://doi.org/10.35870/jemsi.v7i1.510.

\section{ABSTRAK:}

Tiket.com merupakan sebuah aplikasi travel online yang dapat membantu para penggunanya untuk melakukan pemesanan tiket melalui jaringan internet seperti tiket pesawat, tiket kereta api, reservasi hotel dan sebagainya. Pengguna aplikasi Tiket.com banyak didominasi oleh mereka yang membutuhkan kemudahan dalam proses bepergian. Sistem informasi manajemen merupakan sebuah teknologi yang sangat penting dan dibutuhkan oleh para pelaku bisnis untuk meningkatkan kualitas dan pelayanan yang diberikan kepada pelanggan. Tujuan dari penelitian ini adalah untuk mengetahui penerapan sistem informasi manajemen pada aplikasi Tiket.com sudah berjalan secara optimal atau belum dan sebesar apa pengaruh dari penerapan sistem informasi manajemen ini dalam proses kegiatan bisnis. Penelitian ini menggunakan metode analisis data deskriptif dengan membaca referensi buku, artikel dan jurnal yang dibuat oleh para ahli untuk memperoleh data yang akurat sehingga tidak terjadi manipulasi data ataupun hal lainnya. Subjek dari penelitian ini adalah aplikasi travel online yakni Tiket.com. Hasil dari penelitian ini menunjukan bahwa penerapan sistem informasi manajemen telah dilakukan secara maksimal mulai dari penyebaran informasi kepada penggunanya sehingga memberikan kemudahan dan kepuasan tersendiri kepada mereka. Selain itu, dengan diterapkannya sistem informasi manajemen pada aplikasi Tiket.com membawa pengaruh yang sangat baik dalam menunjang kegiatan bisnis.

Kata Kunci: Sistem Informasi Manajemen, Tiket.com.

JEL Classification: L86; D83.

\section{PENDAHULUAN}

Tiket.com merupakan salah satu platform booking tiket online travel, event, dan perhotelan. Perusahaan ini telah beroperasi dengan baik sejak awal didirikannya pada tahun 2011. Awal mula perusahaan ini muncul sebenarnya karena adanya masalah dari masyarakat Indonesia itu sendiri. Minimnya informasi travel menjadi salah satu alasan terbesar mengapa perusahan ini bisa didirikan. Tiket.com ini merupakan aplikasi dari perusahan PT Global Tiket Network yang berfokus pada fitur booking dan ticketing online yang memberikan pelayanan reservasi tiket. (Burnima \& Wardhana, 2017). 
Tiket.com berhasil menjadi agen layanan tiket online kereta api nomor satu dengan berkolaborasi bersama PT Kereta Api Indonesia atau Persero pada akhir tahun 2015. pada tahun tersebut pembelian tiket penerbangan naik sebesar $150 \%$ lebih dari pada tahun sebelumnya dan pembelian tiket hotel juga mengalami lonjakan sebesar $200-300 \%$ dari tahun sebelumnya, kejadian tersebut menjadikan Tiket.com sebagai salah satu agen travel online terbesar di Indonesia. Berdasarkan data yang diperoleh dari alexa.com bahwa situs Tiket.com menduduki posisi ke 111, namun pada tahun 2017 situs Tiket.com mengalami penurunan dan menduduki ranking 315 se-Indonesia (Nurjannah, Kusyanti, \& Herlambang, 2017)

Perkembangan teknologi saat ini telah membuat persaingan dibidang informasi menjadi semakin bebas dan kompetitif. Dengan berkembangnya pembangunan, organisasi publik hingga swasta semakin banyak orang yang mampu memanfaatkan teknologi informasi baru yang dapat menunjang efektifitas, produktivitas, dan efisiensi mereka (Kumorotomo, 1994). Salah satu jenis untuk mengimplementasikan teknologi untuk meningkatkan persainagan bisnis dan penujualan produk ataupun jasa yaitu dengan menggunakan e-bussines sebagai media untuk memasarkan produk ataupun jasa yang berbentuk fisik ataupun digital. Penggunaan teknlogi tersebut memiliki keterkaitan dengan berbagi pihak antar perusahan untuk terus berperan dalam mengembangkan bisnis. Semakin matangnya teknologi internet dan website teknologi ini dapat meningkatkan kemampuan perusahaan dalam hal komunikasi bisnis dan informasi yang akan diberikan. (Hasibuan, Jamaludin, Yuliana, Sudirman, \& Wirapraja, 2020)

Perkembangan teknologi informasi membuat perusahaan untuk menerapkan sistem informasi manajemen pada perusahaan mereka. Dengan menerapkan sistem informasi ini tentunya banyak sekali keuntungan yang ditawarkan yaitu dapat memperlancar kegiatan perusahaan yang dapat menjadi salah satu faktor utama. Selain itu kebutuhan akan teknologi yang setiap harinya terus meningkat pun tidak bisa diabaikan begitu saja (Haris, 2017). Sistem informasi manajemen (SIM) dapat menghasilkan informasi yang handal bagi setiap perusahaan apabila dilakukan pengembangan. Pengembangan ini dapat mencerminkan perusahaan dalam mengelola informasi melalui komputer secara menyeluruh dan terstruktur yang dapat mengubah data menajdi infromasi melalui serangkaian cara yang mampu meningkatkan produktivitas serta kinerja suatu perusahaan dalam menjalankan aktivitasnya. Peran manajemen sangat penting dalam menghasilkan informasi, pemetaan kebutuhan informasi, penentuan jenis dan kualifikasi informasi, dan penggunaan infromasi yang didasarkan kepada core business dan tujuan perusahaan. Dengan kata lain, sistem informasi manajemen memiliki cakupan lebih lluas dari teknologi informasi yang merupakan bagian dari sistem informasi manajemen. (Hutahaean, et al., 2021).

Bagi perusahaan, informasi tersedia tidak hanya di dalam organisasi tetapi juga di luar organisasi. Informasi yang disimpan oleh perusahaan biasanya berupa informasi dalam format data. Data ini disimpan dengan aman di sistem ini. Ketika membuat keputusan, sistem informasi manajemen membantu manajer dalam memahami masalah, menciptakan desain pemecahan masalah, dan memilih solusi pemecahan masalah yang tepat. Data yang tersimpan dalam sistem ini memudahkan dalam pengambilan keputusan. (Paoki, 2021). Penggunaan teknologi informasi yang hingga saat ini terus berkembang ternyata memberikan efek positif, seperti meningkatnya peluang bisnis baru yang tercipta khususnya dengan memanfaatkan media internet. Perkembangan teknologi informasi tersebut memungkinkan setiap orang untuk melakukan kegiatan jual-beli melalui jaringan internet dengan mudah. (Simarmata, et al., 2020). Dalam konteks perkembangan teknologi yang pesat saat ini, penggunaan sistem manajemen informasi merupakan pilihan yang tepat untuk mengolah sumber daya informasi yang berkualitas tinggi. Sistem informasi manajemen dapat membantu menginformasikan tim manajemen dengan berbagai informasi yang tersedia dalam semua bentuk perangkat teknologi kepada setiap pengguna.

Kemajuan zaman saat ini telah mengubah kehidupan masyarakat menjadi lebih baik. Tingginya penduduk indonesia saat ini atau dikenal juga sebagai era globalisasi yang mana semakin kompleks dan aktivitas kebutuhan manusia yang beragam dalam pekerjaan, hiburan, pariwisata, dan perjalanan (Fonna, 2019). Hal ini tentunya sangat mempengaruhi permintaan akan jasa transportasi darat, laut, dan udara, jasa reservasi hotel dan apartement, serta jasa reservasi tiket event.Dengan tiket.com, pemesanan tiket yang dulunya harus dilakukan dengan proses yang panjang dan lama kini bisa dilakukan dengan jauh lebih cepat dan mudah. Prasarana transportasi yang mudah diakses dan memungkinkan orang untuk berpindah dari satu tempat ke tempat lain bisa membuat negara berkembang lebih pesat. Kehadiran tiket.com saat itu menjadikannya sebagai pionir OTA (Online Travel Agency) di Indonesia dari penjualan tiket pesawat, kereta api, dan hotel. 


\section{TINJAUAN KEPUSTAKAAN}

\section{Sistem Informasi}

Menurut Laudon dan Laudon (2013: 47) Sistem informasi adalah seperangkat komponen yang saling berhubungan yang mengumpulkan atau mengambil, memproses, menyimpan, dan mendistribusikan informasi yang mendukung pengambilan keputusan dan pengendalian dalam suatu organisasi. Menurut Hartono (2013:20). Sistem informasi yaitu bagian dari pengendalian internal suatu bisnis yang biasanya mencakup teknologi, maanjemen personalian, dan prosedur administratif untuk memecahkan masalah bisnis yang sedang terjadi. Tujuan dari adanya sistem informasi yaitu untuk menyediakan dan mensistematikan informasi yang merefleksikan seluruh keadaan dan kegiatan yang diperlukan untuk mengendalikan operasi-operasi organisasi, menyediakan informasi yang dipergunakan dalam perencanaan, pengendalian, pengevaluasian dan perbaikan berkelanjutan, dan menyediakan infromasi untuk pengambilan keputusan

Menurut (James A. O'Brien and Marakas, 2010) komponen dasar sistem infromasi bergantung pada lima hal, diantaranya

1. Sumber daya manusia, sumber daya manusia diperlukan untuk pengoperasian sistem informasi apa pun, orang adalah sumber daya pengguna akhir dan ahli dalam sistem informasi.

2. Sumber daya perangkat keras, sumber daya perangkat keras menjadi sumber daya pemrosesan informasi. Media penyimpanan apa pun yang merupakan objek nyata di mana data direkam dari selembar kertas ke disk magnetik atau optik, serta sumber daya mekanis seperti komputer.

3. Sumber daya perangkat lunak, sumber daya perangkat lunak yang dipesan untuk semua perintah pemrosesan data. Secara konseptual, perangkat lunak bekerja atau bekerja dengan perangkat keras komputer yang disebut program, dan sekumpulan instruksi untuk memproses informasi disebut prosedur. Berikut adalah contoh sumber informasi.

a. Sistem Perangkat lunak atau software system adalah program sistem operasi yang mengontrol dan memelihara pengoperasian sistem komputer.

b. Perangkat lunak aplikasi atau software aplikasi merupakan program yang langsung diproses oleh pengguna akhir untuk pengguna tertentu sistem komputer. Contoh: program pengolah kata dan program analisis penjualan.

c. Prosedur, pengoperasian sebuah perintah bagi orang-orang yang akan menggunakan sistem informasi. Contoh: sebuah perintah untuk mengisi formulir menggunakan software

4. sumber Data atau data source merupakan Sistem Informasi beragam dapat berupa angka, huruf, dan simbol lain yang menggambarkan transaksi dan jenis kegiatan bisnis lainnya. Saat membuat pesan, Anda dapat menggunakan data teks berupa kalimat, data gambar seperti grafik, tabel, dan gambar, atau Anda dapat menggunakan format audio dan video.

5. Sumber daya jaringan, intranet dan ekstranet sangat penting untuk komunikasi dan teknologi jaringan dan merupakan dasar untuk bisnis elektronik dan operasi e-commerce dalam sistem informasi komputer. Sumber daya jaringan meliputi:

a. Media komunikasi seperti kabel twisted-pair, kabel tembaga, kabel serat optic, teknologi gelombang mikro, seluler dan satelit tanpa menggunakan kabel

b. Dukungan jaringan, seperti perangkat keras, perangkat lunak, dan dukungan teknis data, diperlukan untuk mendukung operasi dan penggunaan jaringan. Contoh: modem, prosesor gateway, perangkat lunak operasi jaringan, dan perangkat lunak pengontrol seperti browser Internet.

\section{Sistem Informasi Manajemen}

Sistem Informasi manajemen merupakan salah satu penerapan sistem teknologi informasi dan komunikasi pada organisasi bisnis. Menurut Hartono (2013:20) Sistem informasi manajemen yaitu sebuah serangkaian terorganisasi dari sejumlah bagian atau komponen yang secara bersama - sama berfungsi atau bergerak menghasilkan informasi untuk digunakan dalam manajemen perusahaan. Menurut Thomphson dan CatBaril (2003) merupakan sebuah sistem yang terintegrasi berbasis teknologi informasi yang dibuat untuk mendukung operasi, manajemen, dan fungsi pembuatan keputusan dalam suatu organisasi/perusahaan.

Sistem informasi manajemen (SIM) merupakan bagian dari sistem perencanaan pengendalian internal bisnis yang berhubungan dengan pemanfaatan manusai, dokumen, teknologi, dan prosedur dalam akuntansi manajemen untuk memecahkan masalah bisnis, seperti biaya produk, layanan, atau strategi bisnis. Sistem informasi manajemen jelas berbeda dari sistem informasi pada umumnya karena SIM digunakan untuk 
menganalisis sistem informasi lain yang berlaku untuk operasi organisasi. Dari sudut pandang akademis, istilah ini biasa digunakan untuk merujuk pada sekelompok teknologi manajemen informasi yang terkait dengan otomatisasi atau dukungan pengambilan keputusan manusia, seperti sistem pendukung keputusan, sistem pakar, dan sistem informasi.

Sistem informasi manajemen memiliki elemen fisik yang diperlukan untuk kelancaran pengoperasian sistem yang digunakan, seperti perangkat keras komputer, peangkat lunak sistem umum, perangkat lunak terapan umum, serta program asplikasi. Selanjutnya, pada bagian sistem informasi manajemen terdapat database dan langkah pelaksanaan sistem manajemen perusahaan.

Komponen Sistem Informasi Manajemen Menurut Susanto (2004: 34), komponen informasi yang terintegrasi dari suatu sistem bekerja sama untuk menciptakan informasi yang dapat dipercaya oleh pengguna. Dalam konsep sistem informasi manajemen yang terintegrasi, semua elemen dan sub-elemen dihubungkan dengan pembentukan sistem informasi manajemen yang berkualitas. Elemen-elemen ini disebut juga sebagai komponen sistem informasi yang terdiri dari perangkat keras, perangkat lunak, perangkat lunak cerdas, prosedur, basis data, dan jaringan komunikasi. Komponen sistem informasi manajemen menurut Susanto (2004:34),

1. Hardware atau perangkat keras, yaitu peralatan fisik yang dapat digunakan untuk mengumpulkan, menginput, mengolah, menyimpan dan mengeluarkan hasil pengolahan data berupa informasi.

2. Software atau perangkat lunak, yaitu kumpulan dari program-program yang digunakan untuk menjalankan komputer atau aplikasi tertentu pada computer.

3. Brainware, yaitu sumber daya manusia yaitu bagian terpenting dari komponen sistem informasi manajemen.

4. Prosedur yaitu rangkaian aktivitas atau kegiatan yang dilakukan secara berulang-ulang dengan cara yang sama

5. Basis data atau database, yaitu suatu pengorganisasian sekumpulandata yang saling terkait sehingga memudahkanproses pencarian informasi, dan Jaringan komputerdan komunikasi data.

\section{METODE PENELITIAN}

\section{Pendekatan Penulisan}

Metode penelitian ini menggunakan metode analisis data deskriptif. Penelitian ini tidak mengadakan manipulasi atau mengubah variabel bebas, tetapi menggambarkan suatu kondisi apa adanya. Penggambaran kondisi dapat berupa individual atau menggunakan angka-angka. (Fitrah, 2018).

\section{Subjek dan Objek Penelitian}

Pada penelitian ini objek yang dilakukan sebagai sebagai bahan penelitian adalah sistem informasi manajemen. Sedangkan subjek yang digunakan adalah aplikasi Tiket.com.

\section{Teknik Pengumpulan Data}

Metode pengumpulan data yang kami lakukan yaitu dengan studi pustaka, dimana data dikumpulkan dengan cara membaca buku referensi, artikel/makalah, jurnal, dan lain sebagainya yang ditulis oleh para ahli untuk mendukung data-data yang diperlukan dalam analisa sistem informasi manajemen. Selain itu, analisis kebutuhan dilakukan dengan menganalisis pihak-pihak yang berperan dalam implementasi sistem informasi manajemen pada aplikasi Ticket.com.

\section{HASIL PENELITIAN DAN PEMBAHASAN}

\section{Gambaran Umum Perusahaan}

PT Global Tiket Network atau sebuah perusahaan yang pada umumnya dikenal sebagai Tiket.com merupakan salah satu agen travel online diindonesia yang menyediakan berbagai macam pilihan produk seperti tiket pesawat, reservasi hotel, pemesanan tiket kereta api, dan masih banyak fitur lainnya seperti sewa mobil dan pemesanan tiket event yang berkolaborasi dengan Tiket.com. Tiket.com didirikan oleh Natali Ardianto, Wenas Agusetiawan,Dimas Surya Yaputra, dan Mikhael Gaery Undarsa pada bulan agustus tahun 2011. Awalnya Tiket.com hanya menjual tiket hiburan dan pemesanan hotel, namun di tahun 2012 Tiket.com memunculkan 
program bisnis baru berupa pemesanan tiket pesawat. Setelah itu pada tahun 2013 Tiket.com bekerja sama dengan PT KAI untuk menerapkan sistem penjualan tiket kereta api secara online. Hingga akhirnya di tahun 2014 Tiket.com memberikan fasilitas baru berupa sewa mobil secara online, hal inila yang membuat Tiket.com terus berfokus pada bidang travel. pada bulan juni 2014 Tiket.com secara resmi merilis aplikasi mobile pertamanya untuk android.

Aplikasi Tiket.com saat ini diketahui memiliki lebih dari jutaan penguna jasa layanan travel online yang aktif dan telah bekerja sama dengan PT KAI, dan beberpa maskapai penerbangan seperti Lion Air, Air Asia, Citilink, Sriwijaya, dll. Tiket.com juga telah memiliki jaringan mitra dengan lebih dari 200.000 hotel dalam maupun luar negeri. Sumber dari www.alexa.com memberikan informasi bahwa Tiket.com tercatat sebagai sebuah situs yang menempati urutan ranking global ke 11.841, dan menempati ranking 180 di Indonesia. Hal tersebut merupakan suatu prestasi yang luarbiasa karena menunjukkan bahwa situs tersebut stabil

\section{Visi dan Misi}

Menjadi situs Online Travel Agent (OTA) terbaik di indonesia. Agar tercapainya visi tersebut Tiket.com memiliki misi Memberdayakan dan memenuhi kebutuhan pelanggan dengan memberikan pelayanan dan solusi terbaik.

\section{Struktur Organisasi Perusahaan}

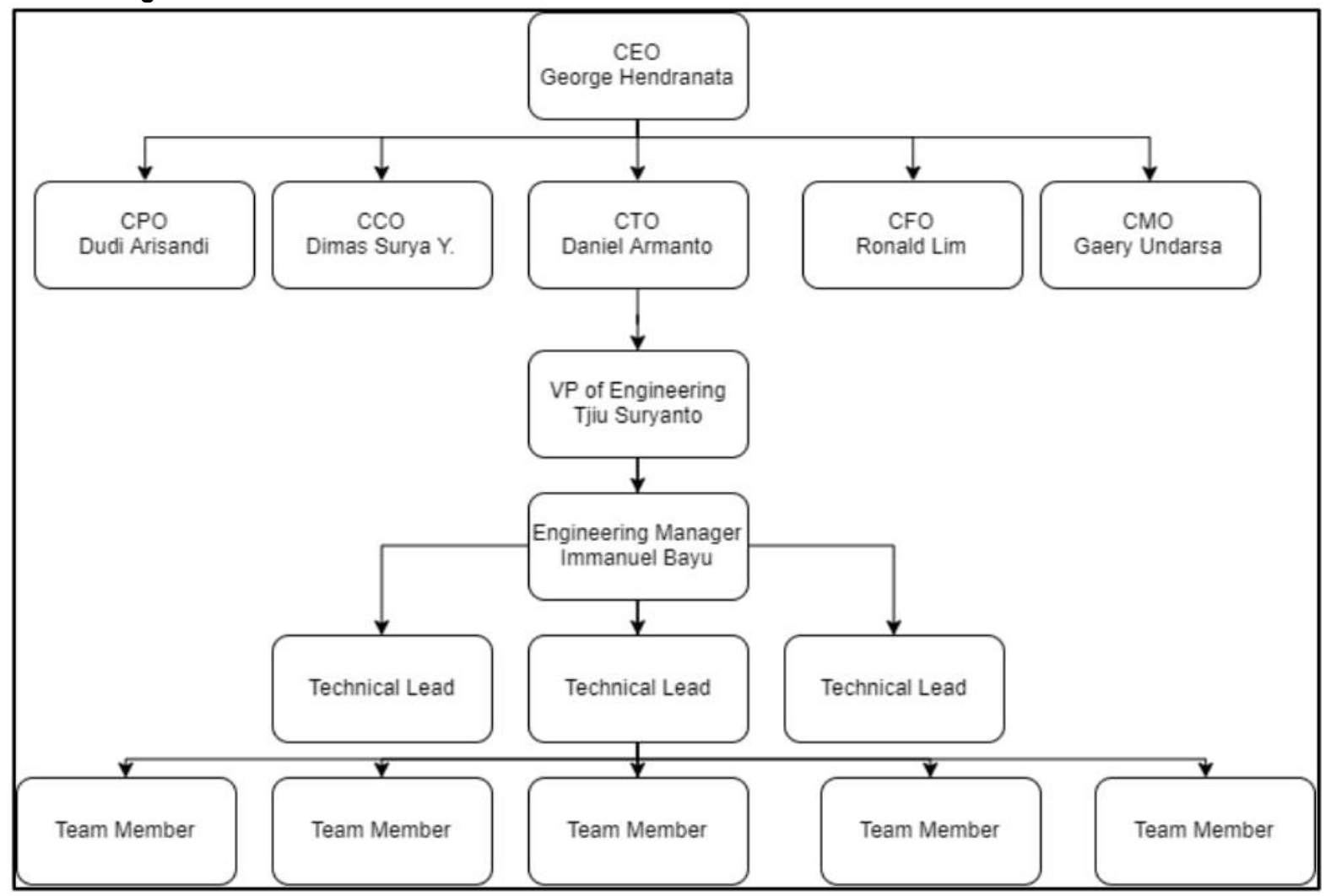

Gambar 1. Struktur Organisasi Perusahaan PT Global Ticket Network atau Tiket.com

PT Global Tiket Network memiliki satu orang dengan jabatan tertinggi yaitu George Hendranata yang menjabat sebagai Chief Executive Officer (CEO). CEO memiliki tugas memutuskan dan menentukan peraturan dan kebijakan tertinggi perusahaan, merancang dan mengomunikasikan visi perusahaan, merekrut dan memotivasi anggota tim, membangun hubungan dengan investor dan memperluas kerjasama dengan penyedia jasa. Dibawah pimpinan CEO terdapat C-Level yang diantaranya :

1. Chief Product Officer (CPO)

Posisi Chief Product Officer (CPO) dijabat oleh Dudi Arisandi. CPO bertanggung jawab atas strategi dan pelaksanaan semua kegiatan yang terkait dengan organisasi atau produk perusahaan. 
2. Chief Compliance Officer (CCO)

posisi Chief Compliance Officer (CCO) yang dijabat oleh Dimas Surya Yaputra memiliki ttanggung jawab untuk memastikan bahwa Perusahaan dan karyawannya mematuhi kebijakan internal Perusahaan.

3. Chief Technology Officer (CTO)

Daniel Armanto menjabat sebagai Chief Technology Officer (CTO), posisi ini bertanggung jawab untuk mengintegrasikan pengembangan produk, pemahaman dan implementasi pengembangan teknologi, dan manajemen pengembangan produk..

4. Chief Financial Officer (CFO)

Ronald Lim menjabat sebagai Chief Financial Officer (CFO), tanggung jawab CFO yaitu merumuskan strategi pembiayaan, menyusun dokumentasi keuangan, mendiskusikan posisi keuangan perusahaan dengan CEO, dan membuat keputusan terkait sumber daya manusia seperti perekrutan, pemecatan, perekrutan, keuntungan, dan akuisisi.

5. Chief Marketing Officer (CMO)

Gaery Undarsa yang menjabat sebagai Chief Marketing Officer (CMO) bertanggung jawab atas semua aspek pemasaran, termasuk riset pasar, dan strategi hubungan masyarakat untuk menjaga citra perusahaan di mata publik.

C-Level memiliki beberapa Vice President (VP) yang memiliki tugas membantu dan mengatur masingmasing divisi. Salah satunya adalah VP of Engineering yang dijabat oleh Tjiu Suryanto. VP of Engineering dibantu oleh engineering manager untuk mengawasi masing-masing Technical Lead yang bertugas memimpin tim kecil.

\section{Sistem Informasi Pemesanan Layanan}

Prosedur pemesanan layanan pada Tiket.com dapat dilakukan dalam beberapa tahap seperti di bawah ini :

a. Melakukan registrasi/pendaftaran terlebih dahulu melalui aplikasi Tiket.com.

b. Melakukan log in agar dapat melakukan pemesanan layanan yang dibutuhkan.

c. Memilih layanan yang akan dipesan

d. Menginput data informasi tujuan

e. Memilih layanan yang tersedia

f. Memilih metode pembayaran, dapat melalui tunai atau e-wallet

\section{Strategi Sistem informasi Manajemen yang digunakan}

Penerapan sistem informasi yang digunakan oleh Tiket.com yaitu dengan melalui tiga tahapan yang disebut dengan customer life cycle. Tahapa-tahapan tersebut yaitu Acquire, Enhance, dan Retain. Pada tahapan Acquire Tiket.com menggunakan teknik direct marketing sebagai langkah promosi melalui social media untuk menarik minat pelanggan. Selanjutnya pada tahapan Enhance Tiket.com bekerja sama dengan beberapa mitra seperti jasa transportasi, penginapan, atau penyelenggara event sehingga hal tersebut dapat menambah pelanggan baru. Tahapan terakhir yang digunakan yaitu Retain, pada tahapan ini Tiket.com berusaha untuk mempertahankan pelanggannya menngunakan teknik customer support di mana perusahaan menanggapi setiap permasalahan dan keinginan pelanggan sehingga dapat terciptanya loyal customer.

Tiket.com menggunakan sistem informasi manajemen Executive Support System (ESS) yaitu sebuah sistem yang oleh para senior manajer/eksekutif sebuah perusahaan atau orgnisasi untuk memberikan dukungan terhadap keputusan yang tidak terprogram dalam manajemen strategis. Informasi ini sering bersifat eksternal, tidak terstruktur, dan bahkan tidak pasti. Lingkup dan konteks informasi yang tepat seringkali tidak diketahui sebelumnya. Informasi yang didapat dengan menggunakan Executive Support System adalah informasi pasar, informasi teknologi, dan informasi investasi. Setelah mengetahui informasi tersebut maka perusaaan dapat menyesuaikan apa yang dibutuhkan oleh pasar agar dapat tercapainya visi perusahaan.

\section{Teknologi Informasi Manajemen yang digunakan}

Dalam memberikan layanan kepada konsumen, Tiket.com memanfaatkan beberapa teknologi informasi seperti teknologi end user yang berupa aplikasi pada smarthphone android dan IOS. Metode pembayaran yang dapat dilakukan pada Tiket.com yaitu dapat menggunakan metode debit/kredit card, ATM, transfer online, virtual account, E-Wallet, Gerai Retail, cicilan tanpa kartu kredit, dan paylater Tiket.com. untuk perihal masalah ataupun 
keluhan pelanggan dapat langsung menghubungi customer service yang terdapat di aplikasi Tiket.com maupun melalui sosial media.

\section{Fitur yang Terdapat pada Menu Utama Layanan Tiket.com}

Terdapat beberapa fitur yang dapat digunakan pada aplikasi Tiket.com untuk memesan tiket transportasi, reservasi penginapan, maupun event. Untuk dapat melakukan pemesanan tiket penerbangan customer dapat melakukan langkah-langkah sebagai berikut:

1. Pilih rute, tanggal, jumlah penumpang, dan kelas tiket penerbangan, kemudian klik "cari penerbangan" untuk memilih jasa penerbangan yang tersedia pada jadwal yang telah diinputkan.

2. Setelah memilih jasa penerbangan, customer diwajibkan untuk mengisi data penumpang sesuai dengan kartu identitas yang berlaku.

3. memilih metode pembayaran yang diinginkan, jika penumpang memiliki kode voucher maka dapat memasukan kode tersebut untuk mednapatkan diskon

4. Setelah pembayaran terkonfirmasi, maka tiket penerbangan akan dikirimkan melalui email.

\section{CRM pada Tiket.com}

Bentuk penerapan Customer Realtionship Management (CRM) pada Tiket.com yaitu dengan melakukan inovasi untuk mempertahankan pelanggan dengan menciptakan program TIX Point. Pada program ini Tiket.com memberikan promo potongan harga pada saat pembelian produk. TIX point memiliki dau jenis member, yaitu:

1. Elite Member

pelanggan yang telah mencapai 200.000 point akan langsung menjadi Elite Member dan TIX Poin bisa langsung digunakan bertransaksi sebagai potongan harga. Untuk mempertahankan Elite Member maka pengguna diharuskan untuk mengumpulkan minimal 100.000 TIX Point selama satu tahun terhitung dari tanggal aktif menjadi Elite Member.

2. Basic Member

Pelanggan yang belum mencapai 200.000 TIX Point otomatis akan menjadi Basic Member dan TIX Point bisa digunakan bertransaksi sebagai potongan harga. TIX Point dapat digunakan sebagai potongan harga minimal sebesar 25.000 point.

Penerapan Customer Relationship Managemen (CRM) pada Tiket.com ini berupa adanya program membership. Program membership ini dilakukan dengan memberikan point kepada pelanggan yang melakukan transaksi tetapi menggunakan point sebelumnya atau reedem point yang telah ada untuk mendapatkan potongan harga. Penerapan CRM pada Tiket.com yatiu bagaimana mereka memakai aplikasi dan website untuk meningkatkan pendapatan perusahaan melalui penjualan jasa layanan reservasi tiket. Informasi yang berada dalam aplikasi berupa informasi perushaan, produk, diskusi antara pelanggan dengan pihak manajemen sampai pada tata cara pemesanan tiket. Dalam mendukung CRM, Tiket.com memberikan frequent-flyer dalam dua bahasa yang berisi informasi terkini perusahaan kepada pelanggan yang loyal melalui e-mail.

\section{KESIMPULAN DAN SARAN}

Berdasarkan penelitian yang diperoleh kami menarik kesimpulan bahwa Sistem informasi memiliki manajemen memiliki peran yang sangat penting dalam suatu perusahaan dalam menunjang kegiatan bisnis, pengambilan keputusan, dan strategi kompetitif perusahaan.SIM juga berberperan penting dalam sisi pelanggan karena dengan danya sistem informasi manajemen ini dapat membantu pelanggan dalam mendapatkan informasi yang diberikan oleh perusahaan. Selain itu penerapan sistem infromasi manajemen pada tiketi.com sudah berjalan dengan baik hal ini dapat dilihat pada struktur aplikasi perusahaan yang memberikan kerangka kerja konseptual tentang bagaimaan cara melakukan pemesanan.

Kelebihan :

1. Adanya kemudahan untuk membeli tiket hanya melalui smartphone

2. Memberikan informasi terkait agen travel melalui aplikasi dengan baik

3. Terdapat program TIX Point yang dapat memberikan keuntungan untuk pelanggan 
Kekurangan :

1. User interface yang cukup menggangu

2. Terlalu banyak langkah langkah pada saaat awal pembelian tiket

\section{Saran}

Bersarakan kesimpulan yang diambil maka diberikan seran:

1. Lebih memakismalkan tampilan antar muka dengan memberikan icon yang sederhana

2. Tidak terlalu banyak pengisian formulir untuk pemesanan tiket.

\section{REFERENSI}

Abidin, Y. (2015). Manajemen Komunikasi: Filosofi, Konsep, dan Aplikasi. Bandung: Pustaka Setia.

Burnima, R. D., \& Wardhana, A. (2017). Analisis Kualitas Website Tiket.com. Jurnal Ekonomi dan Bisnis Dharma Andalas, 82.

Fitrah, M. (2018). Metodologi penelitian: penelitian kualitatif, tindakan kelas \& studi kasus. CV Jejak.

Fonna, N. (2019). Pengembangan Revolusi Industri 4.0 dalam Berbagai Bidang. Guepedia.

Haris, M. A. (2017). Analisis Penerapan SIstem Informasi pada PTGO-JEK Indonesia.

Hartono, B. (2013). SIstem Informasi Manajemen Berbasis Komputer. Jakarta: Rineka Cipta.

Hasibuan, A., Jamaludin, J., Yuliana, Y., Sudirman, A., \& Wirapraja, A. (2020). E-Business: Implementasi, Strategi dan Inovasinya. Yayasan Kita Menulis.

Hutahaean, J., Purba, R. A., Siagian, Y., Heriyani, N., St Amina, H. U., \& Syah, A. Z. (2021). Pengantar Sistem Informasi Manajemen. . Yayasan Kita Menulis.

Kumorotomo, w. (1994). Sistem Informasi Manajemen. Yogyakarta: Gava Media.

Laudon, K., \& Laudon, J. (2013). Management Information System: Managing the Digital Firm. Pearson Education Limited.

Nugroho, A. (2010). Rekayasa Perangkat Lunak Berbasis Objek dengan Metode USDP. Yogyakarta: Andi.

Nurjannah, Kusyanti, A., \& Herlambang, A. D. (2017). Evaluasi Kualitas Layanan Situs Tiket.com Terhadap Kepuasan Pengguna Menggunakan Webqual dan Importance - Performance Analysis (IPA). Jurnal Pengembangan Teknologi Informasi dan IImu Komputer e-ISSN, 2548, 964X.

Simarmata, J., Chaerul, M., Mukti, R. C., Purba, D. W., Tamrin, A. F., \& Jamaludin, J. (2020). Teknologi Informasi: Aplikasi dan Penerapannya. Yayasan Kita Menulis 